\title{
POSTFIRE: A model to map forest fire burn scar and estimate runoff and soil erosion risks
}

\author{
D.M. Fox ${ }^{\text {a,*, }}$ Y. Laaroussi ${ }^{\text {a }}$, L.D. Malkinson ${ }^{\mathrm{b}}$, F. Maselli ${ }^{\mathrm{c}}$, J. Andrieu $^{\mathrm{a}}$, L. Bottai ${ }^{\mathrm{d}}$, \\ L. Wittenberg ${ }^{\mathrm{b}}$ \\ a UMR ESPACE 7300 CNRS, University of Nice Sophia Antipolis, Nice, France \\ ${ }^{\mathrm{b}}$ Department of Geography, Haifa University, Haifa, Israel \\ c IBIMET-CNR, Florence, Italy \\ d Laboratory for Meteorology, Climatology and Environmental Modelling, LaMMA-Regione Toscana, Florence, Italy
}

\section{A R T I C L E I N F O}

\section{Article history:}

Received 22 April 2016

Received in revised form

12 July 2016

Accepted 15 July 2016

Available online 21 July 2016

Keywords:

Burn scar classification

Forest fire

Runoff

Soil erosion

Risk model

\begin{abstract}
A B S T R A C T
Forest fires in the Euro-Mediterranean region burn about 450,000 ha each year. Combustion of standing vegetation and the leaf litter leave the soil bare and vulnerable to runoff and erosion thereby increasing downstream risks of flooding. Typically, wildfires near or in the Wildland Urban Interface (WUI) occur on uplands and runoff generated from the burned area concentrates downstream in high density urban areas. Local authorities must decide on a range of post-fire measures to mitigate risks quickly since most large fires occur late in summer shortly before the fall-winter rainy season. A GIS-based model that maps the burn scar and quantifies fire impacts on runoff and soil erosion is a useful tool in defining a strategy. The POSTFIRE model executes 54 routines semi-automatically in IDRISI TerrSet and maps the burn scar using pre and post-fire satellite images, calculates the impact of a fire on total rainfall event runoff, and maps soil erosion rates. In addition to satellite images, the model requires a Digital Elevation Model (DEM), a mask of the general contour of the fire, land cover map, and tables of runoff coefficients and sediment concentration values for the land covers. All other input files are generated automatically by the model.

Burn scar classification, runoff and soil erosion maps were compared for two fires in SE France based on SPOT and Landsat images. Differences in burn scar area estimated from unsupervised KMeans classifications of dNDVI and dNBR indices range from 3\% to 15\% depending on the fire. dNDVI burn scars had slightly greater areas than dNBR derived maps, and SPOT burn scar classifications were slightly greater in area than from Landsat images. Estimated post-fire stream discharge values were about 2-2.5 times greater than pre-fire values and differed by less than $10 \%$ between indices and sensors. Similarly, postfire erosion rates (2.0-2.5 $\mathrm{T}^{-1}$ ) were consistent among indices and sensors and coherent with field measurements of erosion. Preliminary results indicate the model is simple to use, adaptable to local conditions, and provides realistic outputs for the burn scar, discharge, and soil erosion maps after a forest fire. Model modules, instructions, and sample data can be downloaded here: https://goo.gl/PjDv68.
\end{abstract}

(c) 2016 Elsevier B.V. All rights reserved.

\section{Introduction}

Globally, fires burn more than 300 Mha $\mathrm{h}^{-1} \mathrm{y}^{-1}$ (Chuvieco et al., 2016), and forest fires burn about 450,000 ha $y^{-1}$ in Mediterranean Europe (Bassi and Kettunen, 2008; JRC Technical Report, 2013). The number of fires and area burned are expected to increase with global warming (Moriondo et al., 2006). Within Europe, Portugal and Greece have been particularly affected by extreme summer fires compared to earlier periods (Bassi and

\footnotetext{
* Corresponding author.

E-mail address: fox@unice.fr (D.M. Fox).
}

Kettunen, 2008). Italy also experienced unusually high burned areas in 2007 and 2012 (JRC Technical Report, 2013). Firefighting strategies might offset some of the potential threat posed by an increase in summer fire-prone weather (Fox et al., 2015), but the buildup of vegetation with increased fire suppression may progressively lead to larger more severe fires in extreme weather conditions.

Forest fires kill people and destroy buildings and infrastructures, and the combustion of vegetation and the litter layer damages natural habitats. In addition, most large Mediterranean forest fires occur late in summer and leave the soil bare and vulnerable to storms which can cause severe runoff and soil erosion (Lavabre and Martin, 1997; Inbar et al., 1998; Shakesby, 2011). The 
increase in runoff in burned forests located in the upper parts of catchments poses flooding risks in urban and agricultural zones located downstream.

Post forest fire management aims at reducing flood and erosion risks, but the time interval between a major fire and the definition of priority sites is short - often in the order of weeks since administrative procedures, financial estimates, and the construction of check dams and other techniques require several more weeks. Defining the magnitude of the burn scar and estimating its potential impact on runoff and erosion must therefore be done quickly. A post-fire burn severity, runoff and erosion model is a useful tool in estimating potential risks (Miller et al., 2015).

Euro-Mediterranean regions share common forest fire risk characteristics. They have relatively high population densities, so even small fires can be dangerous, and much of the coastal lowland area is developed and vulnerable to flooding. In some countries, databases at the national level are easily available and the models themselves are frequently elaborated by state agencies, so harmonizing data and procedures is simplified: Moody and Martin (2015), for example, present a post-fire modeling strategy that uses standardized national input data and digital tools to facilitate local remediation strategies in the USA. Similarly, a web-based interface for the Water Erosion Prediction Project (WEPP) watershed model (Flanagan et al., 2013) and a database that provides standardized national WEPP inputs (Miller et al., 2015) facilitates erosion prediction. In Europe, considerable progress has been made in geospatial data harmonization thanks to the INSPIRE directive (http://inspire.ec.europa.eu/), and European scale research funding has contributed immensely to fire and post-fire management issues, but there is no common post-fire model for managing runoff and erosion risks. Forest fires around the world present similar risks and issues. In the absence of nationally supported tools, post forest fire risk modeling must operate in an opensource or commercially available GIS environment. The model must run on easily accessible input data in order to be operational quickly and should provide a quantitative estimate of what the likely consequences on runoff and erosion will be for rainfall events of different magnitudes. Due to the patchy nature of forest fires, the model must also be spatially distributed (Cawson et al., 2013). The objective of this paper is to present a post-fire model (POSTFIRE) that maps the burn scar, quantifies potential runoff risk, and estimates soil erosion rates. A step-by-step description of the model is provided online (https://goo.gl/PjDv68), so the following sections will focus on the objectives and strategic choices of each of the modules in turn. In addition, results for two burn scars in Mediterranean France will be shown. The article ends with a discussion of model strengths and weaknesses.

\section{Model description}

The POSTFIRE model runs in IDRISI TerrSet (Eastman, 2016) GIS software and semi-automatically implements a sequence of 54 routines grouped into 13 macro modeler sub-modules in 3 objective-specific modules -1 ) burn scar mapping, 2) runoff estimation, and 3) soil erosion mapping (Table 1). Essential input layers are the following: pre and post-fire satellite imagery, a Digital Elevation Model (DEM), a land cover map, a mask outlining the general contour of the fire, a table that assigns runoff coefficients to land cover categories, and a table that attributes sediment concentration values to the combined land cover and slope categories. Other input layers and tables are either derived from these layers or easily computed (unit conversion factors....).

\subsection{Description of fires and satellite imagery}

The model was tested on two burn scars from fires that occurred in 2003 near St Tropez in SE France. The COGOLIN fire occurred 31 August (2726 ha) (Fig. 1a \& b). The second burn scar (VIDAUBAN) is the result of fires on 17 July (6744 ha) and 28 July (5646 ha) in close proximity to one another (Fig. 1c and d). The year 2003 was the hottest summer on record in France and the 3 fires considered here were the 3 largest fires in SE France for that year, and no larger fire has occurred since then. Burned surface area values reported here were drawn from the Prométhée fire database (www.promethee.com), a national database where burned area and cause are recorded by firefighting services. The cause of all three fires was criminal.

Pre and post-fire Landsat 5 and SPOT 5 satellite images (Fig. 1) were obtained for burn scar mapping, and all fires were located within the same Landsat and SPOT images, respectively. All images date from 2003 and the Landsat images date from 12 July (pre-fire) and 1 September (post-fire) while SPOT images date from 22 April (pre-fire) and 3 September (post-fire). Spatial resolutions were $30 \mathrm{~m}$ and $10 \mathrm{~m}$ for the Landat and SPOT images, respectively. Spatial resolutions of all other files (DEM, land cover...) were adjusted to correspond to satellite image cell sizes. In addition, for each burn scar, a common window was defined for all input images so that cell size and the number of columns and rows were identical for all files. There was no cloud cover in any of the pre-

Table 1

MODULE and sub-module summary description.

\begin{tabular}{|c|c|}
\hline MODULE / Sub-module & Description \\
\hline I. BURN SCAR CLASSIFICATION & Maps the burn scar \\
\hline I.1) dNDVI & Calculates dNDVI from pre and post-fire satellite imagery \\
\hline I.2) dNBR & Calculates dNBR from pre and post-fire satellite imagery \\
\hline I.3) Fire scar & Creates three burn scar images based on an automatic classification of dNDVI, dNBR, and dNDVI \& dNBR combined \\
\hline II. RUNOFF ESTIMATION & Quantifies the potential impact of the fire on runoff \\
\hline II.4) Initial input files & Generates initial input files (fire factor, rainfall, runoff coefficients) needed for estimating runoff values \\
\hline II.5) Infiltration before fire & Generates pre-fire infiltration image \\
\hline II.6) Infiltration after fire & Generates post-fire infiltration image \\
\hline II.7a) Runoff calculation (mm) & $\begin{array}{l}\text { Calculates pre and post-fire runoff (in } \mathrm{mm} \text { ), the increase in runoff due to the fire, and the ratio of post to pre-fire } \\
\text { runoff }\end{array}$ \\
\hline II.7b) Runoff calculation $\left(\mathrm{m}^{3} \mathrm{~s}^{-1}\right)$ & $\begin{array}{l}\text { Calculates pre and post-fire mean discharge }\left(\text { in } \mathrm{m}^{3} \mathrm{~s}^{-1} \text { ), the increase in runoff due to the fire, and the ratio of post to }\right. \\
\text { pre-fire runoff }\end{array}$ \\
\hline III. SOIL EROSION MAPPING & Maps estimated soil erosion rates \\
\hline III.8) Sediment concentration before fire $\left(\mathrm{T} \mathrm{m}^{-3}\right)$ & Creates a pre-fire sediment concentration $\left(\mathrm{T} \mathrm{m}^{-3}\right)$ layer based on land cover and slope conditions \\
\hline III.9) Sediment concentration after fire $\left(\mathrm{T} \mathrm{m}^{-3}\right)$ & Creates a post-fire sediment concentration $\left(\mathrm{T} \mathrm{m}^{-3}\right)$ layer based on burn scar, land cover and slope conditions. \\
\hline III.10) Erosion before fire $\left(\mathrm{T} \mathrm{ha}^{-1}\right)$ & Maps pre-fire soil erosion rates $\left(\mathrm{T} \mathrm{ha}^{-1}\right)$ \\
\hline III.11) Erosion after fire $\left(\mathrm{T} \mathrm{ha}^{-1}\right)$ & Maps post-fire soil erosion rates $\left(\mathrm{T} \mathrm{ha}^{-1}\right)$ \\
\hline III.12) Difference erosion & Calculates the difference in erosion between pre and post-fire conditions \\
\hline
\end{tabular}



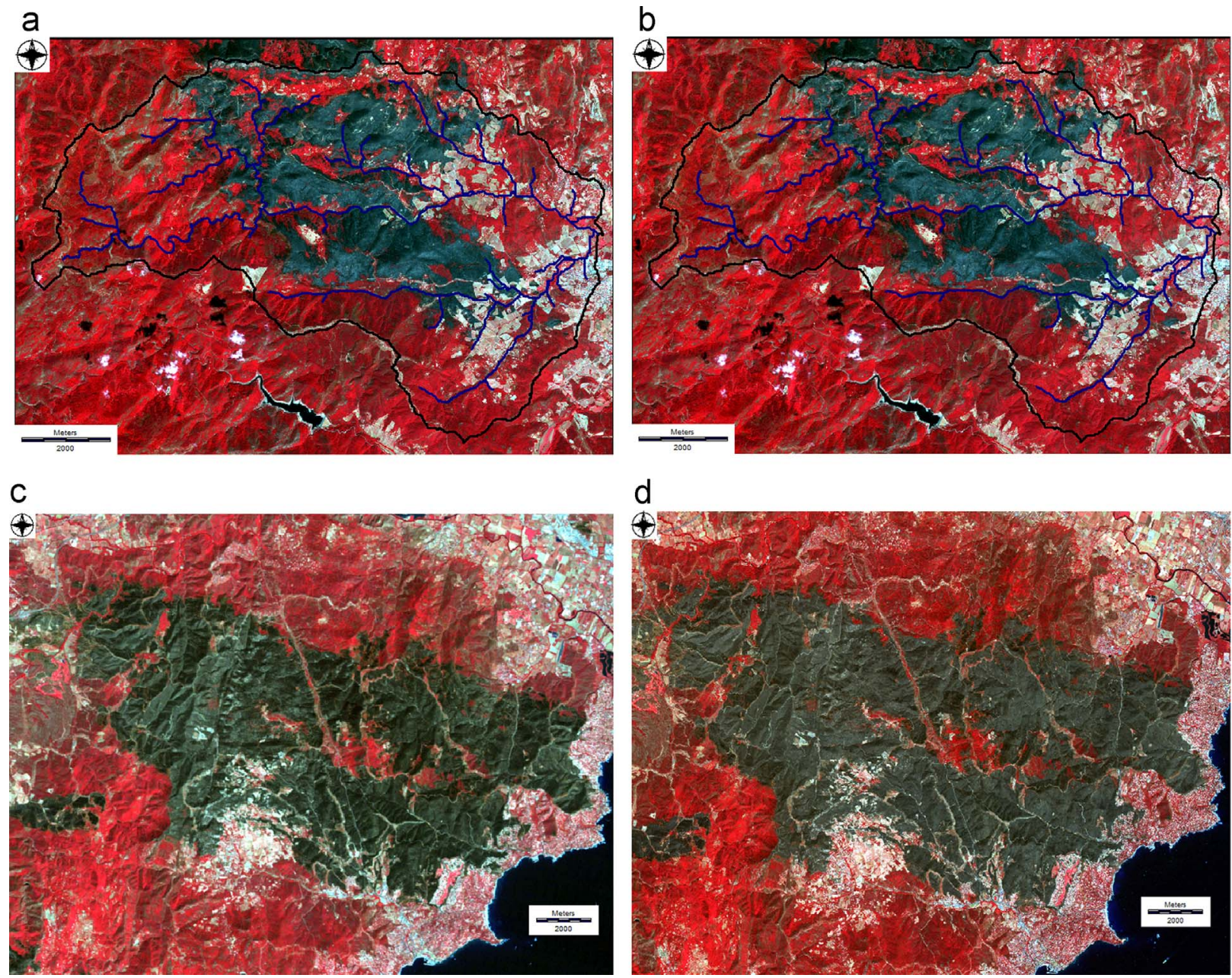

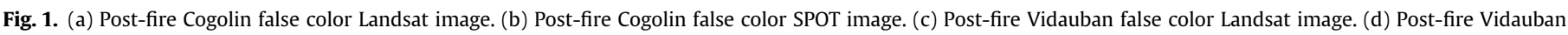
false color SPOT image.

fire images and very little in the post-fire images; only the Cogolin Landsat image (Fig. 1a) has patches of cloud cover near the burn scar.

\section{Burn scar mapping from satellite imagery}

No single universally adopted definition of burn severity exists (Key and Benson, 2006; Vieira et al., 2015), though the Composite Burn Index (CBI) provides a ground method to standardize burn severity interpretation (Key and Benson, 2006). Burn severity influences runoff and erosion rates, and high severity fires, where leaf litter and smaller live vegetation are entirely consumed, are most likely to generate post-fire runoff and erosion (Shakesby, 2011; Vieira et al., 2015). Mapping the clearly distinguishable burn scar is therefore the first step in estimating post-fire runoff and erosion risks.

Several remote sensing techniques have been tested to map burn severity (Rogan and Yool, 2001; Lentile et al., 2006; Sunderman and Weisberg, 2011; Goodwin and Collett, 2014), but the most frequently used are the Normalized Burn Ratio (NBR), where NBR $=($ NIR-MIR $) /($ NIR + MIR $)$, and Normalized Differenced Vegetation Index (NDVI) NDVI $=(\mathrm{NIR}-\mathrm{R}) /(\mathrm{NIR}+\mathrm{R})$ (Cocke et al., 2005; Maselli et al., 1996; Key and Benson, 2006; Miller et al., 2015). Frequently, multi-temporal images are used and post-fire values are subtracted from pre-fire values to provide a differenced NBR $(\mathrm{dNBR})$, where $\mathrm{dNBR}=\mathrm{NBR}_{\text {pre-fire }}-\mathrm{NBR}_{\text {post-fire, }}$ and/or a differenced NDVI (dNDVI), where dNDVI $=\mathrm{NDVI}_{\text {pre-fire }}-\mathrm{NDVI}_{\text {post- }}$ fire. Large positive values of dNBR or dNDVI indicate greater fire severity (Key and Benson, 2006).

The first POSTFIRE module maps the burn scar based on dNBR, dNDVI, and dNBR \& dNDVI values combined. One of the difficulties in mapping burn severity is the definition of threshold values used to separate severity categories, and these are defined subjectively by the user based on ground and/or satellite image interpretation (Fox et al., 2008). The automatic identification of burned areas is a complex issue which has been addressed by several methods (Chuvieco et al., 2002). In general, fully burned pixels can be identified quite easily using two (pre- and post-fire) images, but problems arise where burn severity is low or moderate. This often corresponds to fire boundaries where attribution to burned or unburned cases can be problematic even by field survey. The application of manually identified thresholds to image bands or vegetation indices is a common option which is, however, partly subjective and difficult to automatize. Other, more sophisticated methods, such as those based on the identification of "core burned" pixels and the subsequent application of region growing algorithms, are laborious and require the setting of several parameters (Bastarrika et al., 2011). Thus, a relatively simple method based on an unsupervised KMeans classification of dNBR, dNDVI, and dNBR \& dNDVI combined images is currently preferred. This method avoids defining sensor specific thresholds for each fire and provides greater efficiency in data treatment, but does not solve the boundary pixel problem completely. The limits of burned/ 

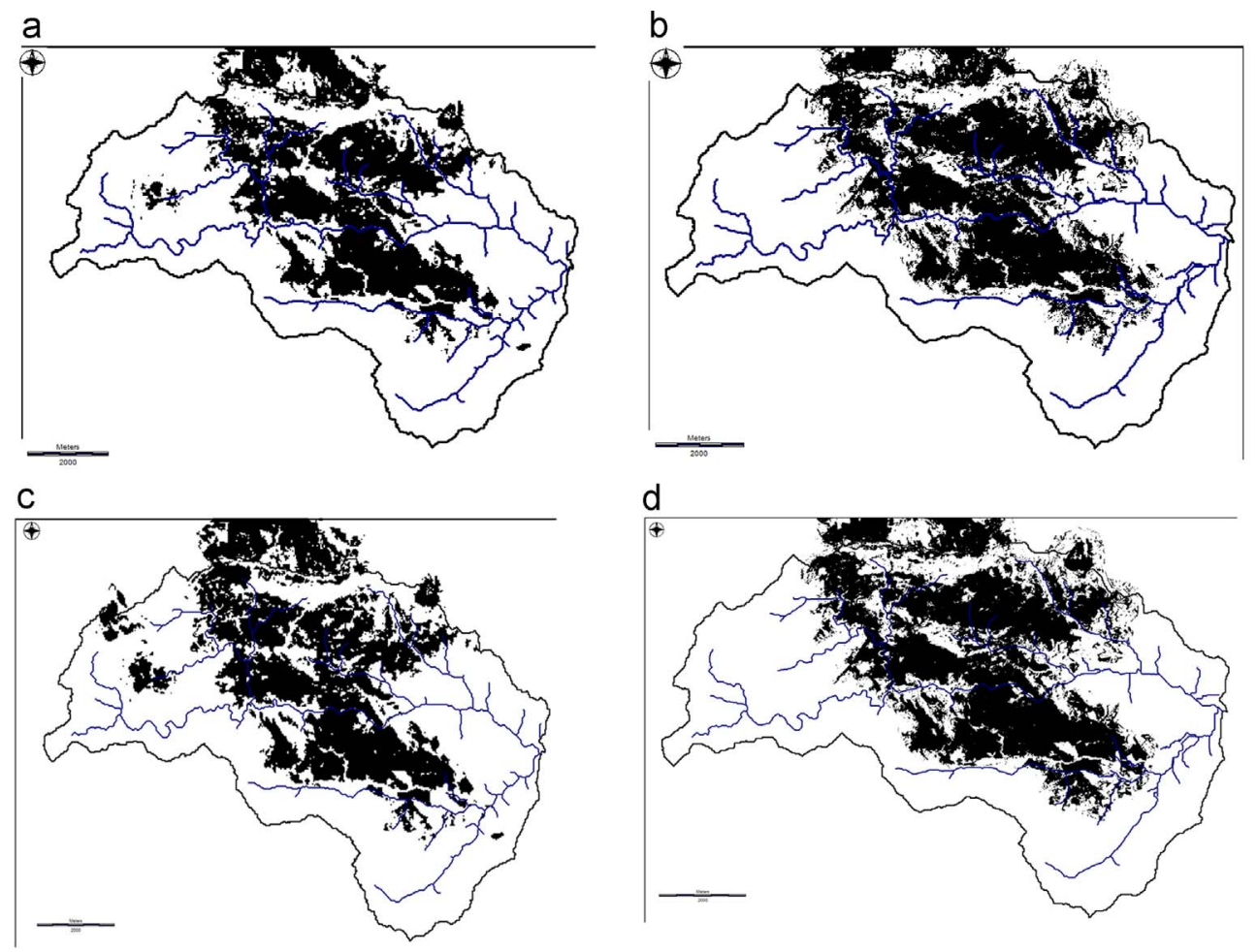

e
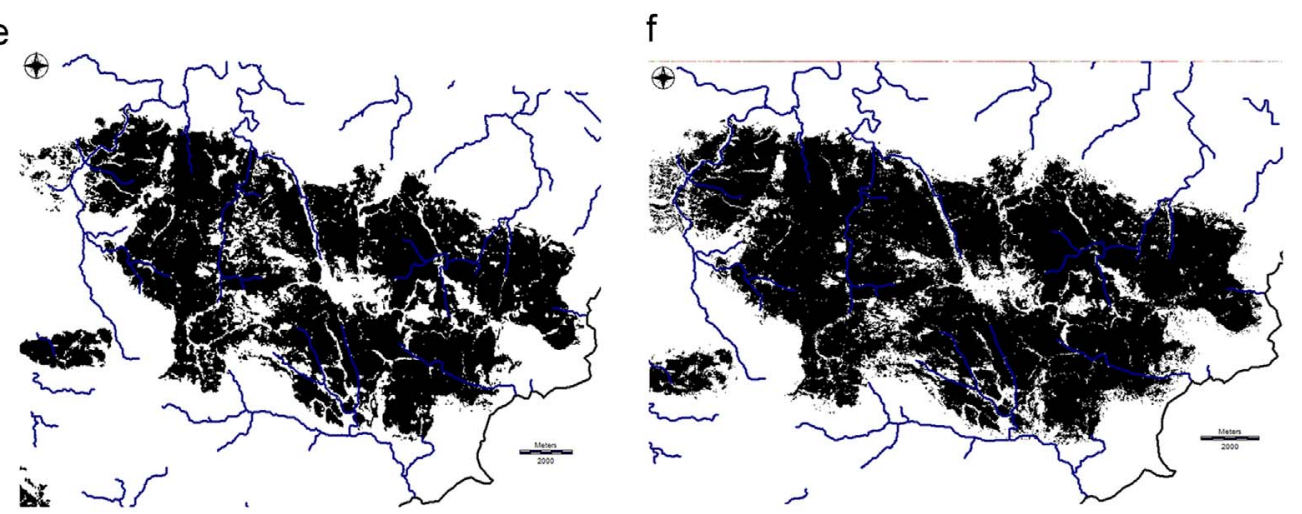

g

h
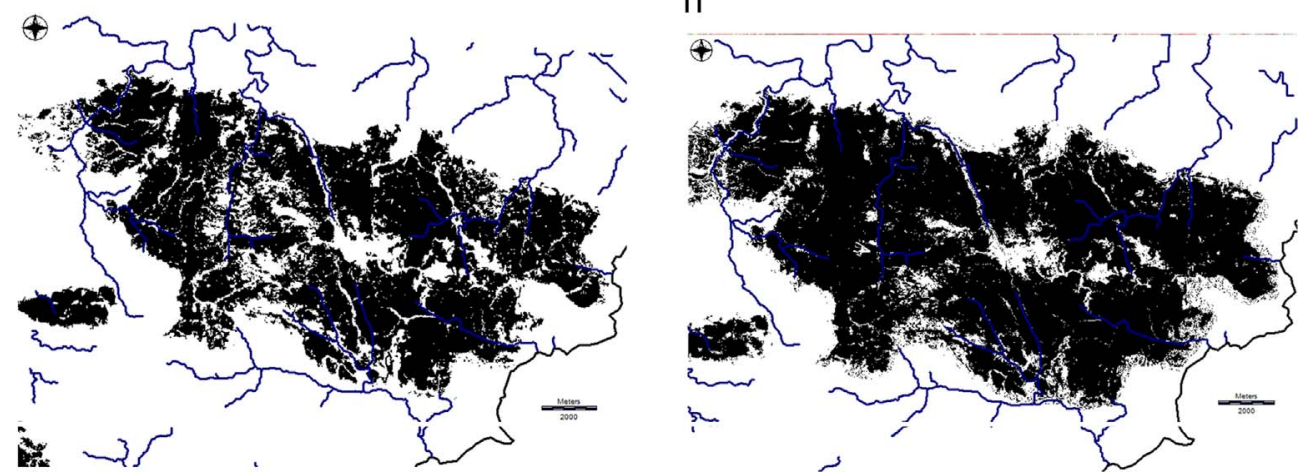

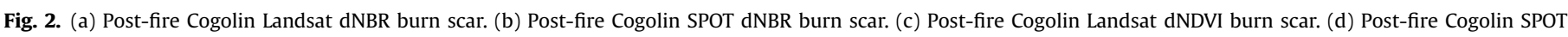

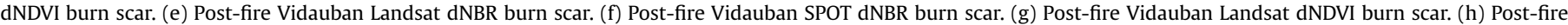
Vidauban SPOT dNDVI burn scar.

unburned areas therefore remain difficult to define, which inevitably introduces uncertainty in the area estimate of fire affected regions. Vegetation within and around the fire perimeter can undergo changes that are independent of the fire, and the mechanical destruction of vegetation causes an increase in dNBR and dNDVI values that can potentially be mapped as a burn scar. In order to minimize this, the KMeans classification includes a mask extending slightly beyond the visually detectable fire perimeter in order to minimize commission errors, as was done by Fox et al. (2008) and Sunderman and Weisberg (2011).

Fig. 2 shows the dNBR and dNDVI burn scars for the Cogolin (Fig. 2a-d) and Vidauban (2e-h) fires, respectively. Although the 

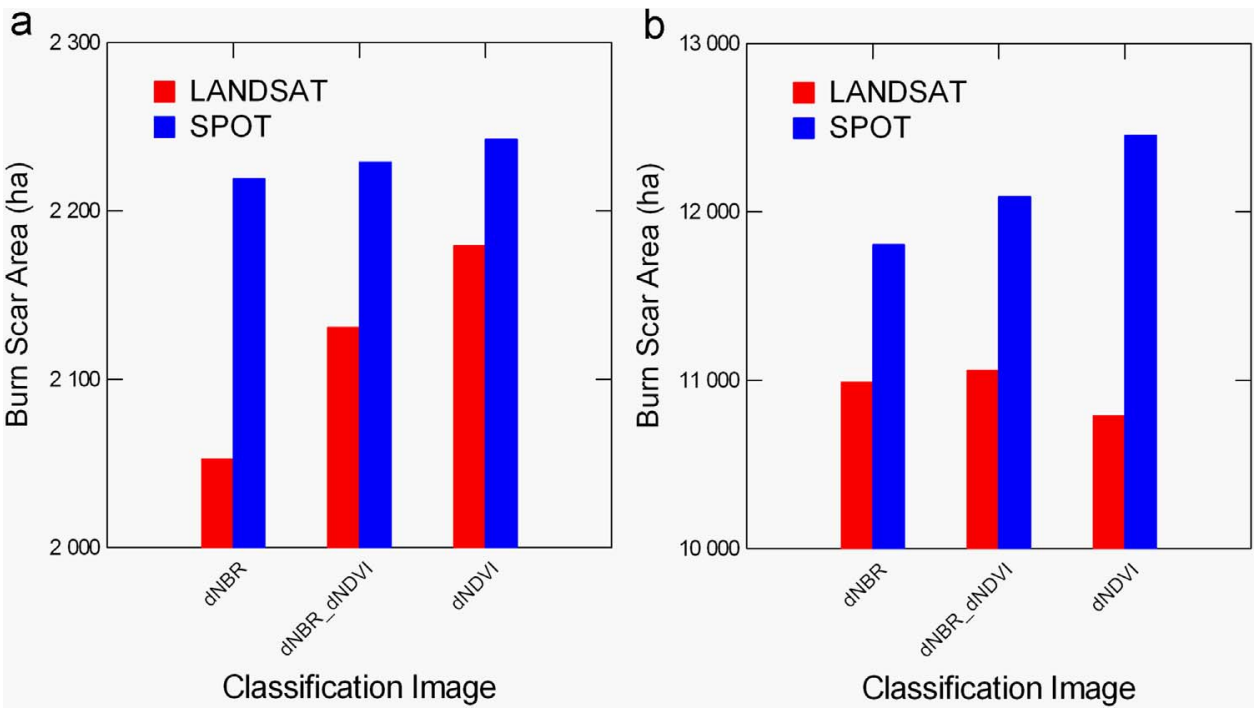

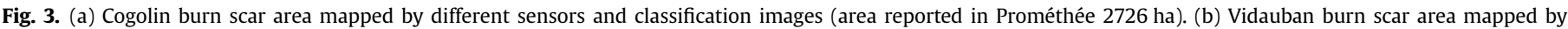
different sensors and classification images (area reported in Prométhée 12,390 ha).

general burn scar patterns derived from the different sensors are similar, burn scars mapped from the SPOT images appear slightly larger than for the Landsat images for both the Vidauban and Cogolin fires. The only obvious anomaly is the inclusion of the cloud shadow (Fig. 2a) in the Landsat dNBR image and cloud and shadow (Fig. 2c) in the Landsat dNDVI in the burn scar

Fig. 3 confirms that SPOT images classify larger areas as burned regardless of the index used. For Cogolin (Fig. 3a), the difference is greatest for dNBR (8.1\% more area) and least for dNDVI (2.9\% more area). For Vidauban (Fig. 3b), the area ranges from $7.4 \%$ (dNBR) to $15.4 \%$ (dNDVI) greater. SPOT trends are consistent for both fires, increasing in area from dNBR to dNDVI with intermediate values for dNBR \& dNDVI combined. Landsat behaves slightly differently for the two fires: for Vidauban (Fig. 3a), values are relatively constant with a slight decrease in burned area for the dNDVI, but for Cogolin (Fig. 3b) the trend is the same as SPOT. However, the greater area classified as burned for the Landsat dNDVI is probably simply an overestimation due to the cloud cover in the image (see Figs. $1 \mathrm{a}$ and 2c).

SPOT appears to be more sensitive to subtle changes in reflection, perhaps because of less mixed area in pixels - cell size is $100 \mathrm{~m}^{2}$ for SPOT compared to $900 \mathrm{~m}^{2}$ for Landsat. Overall, differences between sensors and methods remain acceptably small, though values slightly underestimate areas reported in Prométhée, especially for Cogolin. When the results were shown to local firefighters, they agreed that the Cogolin burned area was probably overestimated in the Prométhée database (personal communication).

\section{Post-fire runoff}

Removal of the litter layer and vegetation undergrowth favors greater runoff coefficients (RC), and these can be enhanced by the presence of hydrophobic compounds on soil material depending on soil temperature during the fire, vegetation, and soil texture among other factors (Doerr et al., 2000; Robichaud and Hungerford, 2000; Cawson et al., 2013). A complete literature review of fire impacts on runoff and erosion is beyond the scope of this paper and has been undertaken by others (Shakesby, 2011; Moody et al., 2013). The impacts of fire on runoff are complex and depend on fire patchiness and severity, the extent of post-fire water repellency, rainfall characteristics, soil depth and texture, and vegetation regrowth; other factors are also important, including the total area and percentage of catchment burned (Prosser and Williams, 1998; Shakesby, 2011; Cawson et al., 2013). Complex interactions between these factors and the scarcity of post-fire runoff measurements at different scales (Shakesby, 2011) make it difficult to predict post-fire runoff. In addition, landscape scale interactions come into play as runoff flows over different surfaces, from burned to unburned forest (Cawson et al., 2013), and onto agricultural or other land covers.

In the IDRISI RUNOFF routine, total runoff is calculated from rainfall (R), infiltration (I) and Digital Elevation Model (DEM) layers. Initial rainfall absorption and event duration are additional options, but these are not exploited here. Both rainfall and infiltration can be spatially varying at the cell scale, and all layers must have the same resolution and number of columns/rows. By initially defining the rainfall event of interest, and with the aid of land cover specific RC values (Fig. 4 and Table 2), pre-fire infiltration (I) can be calculated, where $\mathrm{I}=\mathrm{R}-(\mathrm{RC} * \mathrm{R})$. The model calculates cumulative runoff for each cell in the same units as the input layers (mm), so runoff coefficients are used to calculate the infiltration layer used in the runoff model. If rainfall exceeds infiltration, then runoff flows downslope along the steepest gradient to the lower cell. Runoff for this cell will therefore be calculated as the difference between the sum of rainfall and runon from upslope and infiltration for that cell... Runoff coefficients vary with rainfall depth: they can equal 0 for small events and increase with rainfall depth and intensity (Chow et al., 1988). Few authors relating land cover to runoff coefficients report return periods for the values cited, but they generally represent values for substantial rainfall events: values cited in Chow et al. (1988), for example, are for return periods ranging from 2 to 500 years.

Quantifying burn scar impact on runoff requires a coefficient that decreases infiltration in the burn scar. Defining the magnitude of the decrease is critical, and a wide range of values has been reported in the literature according to rainfall intensity, fire severity, and spatial scale in particular (Inbar et al., 1998; Shakesby, 2011; Cawson et al., 2013). The impact of a fire on runoff is less perceptible at the catchment scale than at the plot scale as runoff generated on the burn scar can subsequently flow over areas of high infiltration in unburned forest or other land covers (Cawson et al., 2013). These processes are accounted for in the POSTFIRE model by spatially varying infiltration. The most appropriate impact values for the burn scar are to be found in studies of moderate 
a

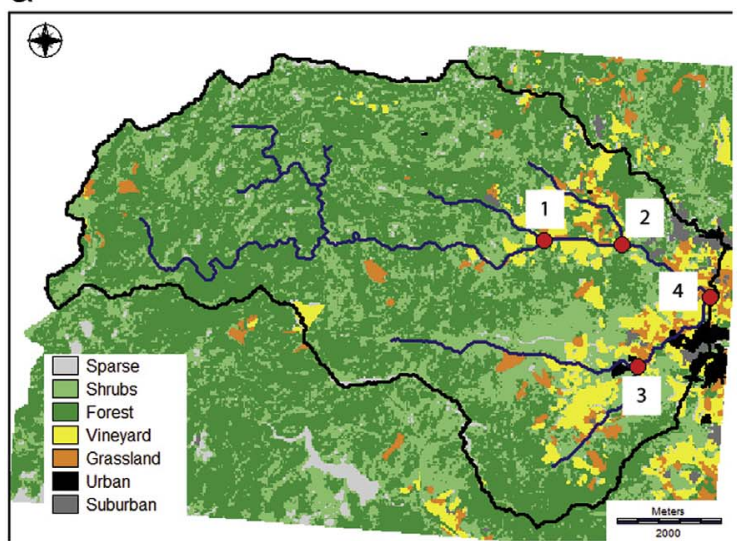

b

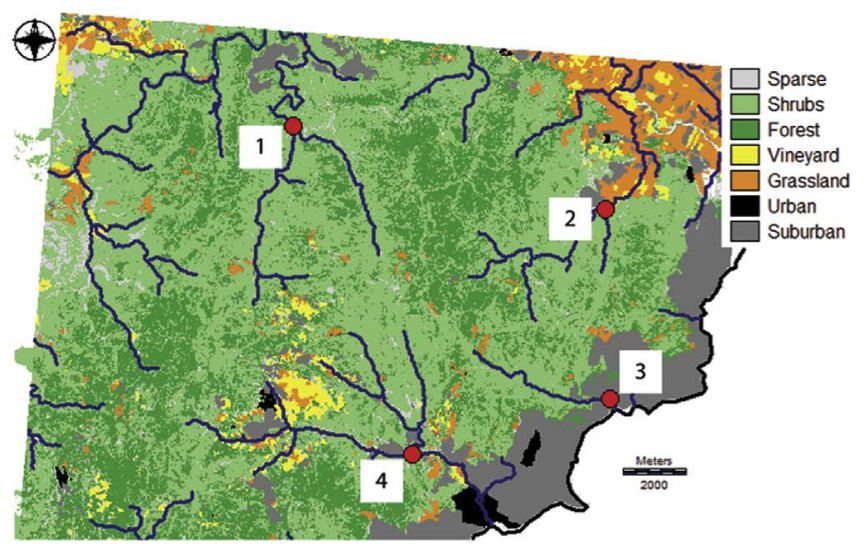

Fig. 4. (a) Land cover map of Cogolin with locations (ID) for discharge comparisons. (b) Land cover map of Vidauban with locations (ID) for discharge comparisons.

to high severity fires at the plot scale, but even in this category, fire impacts on runoff vary greatly. Vieira et al. (2015) provide an extensive review of fire severity impacts on runoff and erosion based on a meta-data analysis of plot scale rainfall simulation experiments, and they found that runoff was about 2.27 times greater on burned than unburned forest. Others (Inbar et al., 1998; Cawson et al., 2013) found much greater increases from - 100 to 500 times - for large events. In this demonstration, post-fire infiltration in the burn scar was half the pre-fire value. Infiltration values for pre and post-fire conditions are shown in Table 2.

Fire has little impact at low rainfall intensities and depths since most of the rainfall is below critical thresholds for runoff (Cawson et al., 2013). In addition, most post-fire runoff and erosion is generated by only the few largest events (Inbar et al., 1998; Cawson et al., 2013), so appropriate rainfall events for the model should have a return period ranging from 1 to 2 years in the autumn/winter since the probability that such an event will occur after a fire is high. This range is also compatible with the runoff coefficient values used for different land covers. Greater rainfall depths (with 5-10 year return periods, for example) can be simulated easily in the model since only the rainfall layer needs to be modified, and all other variables are adjusted automatically. Extreme events, however, cannot be modeled automatically with confidence since infiltration values would increase unreasonably with extreme rainfall. For this demonstration of the model, a daily rainfall depth of $60 \mathrm{~mm}$ was selected based on 31 years (19752005) of daily rainfall measurements for which the return period is about 1.5-2 years. Both rainfall input and runoff output were considered to occur within a day, but actual rainfall occurred over a shorter period within the day; temporal rainfall data at a time scale less than a day was not available. The default runoff output units are the same as the rainfall and infiltration inputs ( $\mathrm{mm})$, but conversion to mean daily discharge in $\mathrm{m}^{3} \mathrm{~s}^{-1}$ makes the units more comprehensible to most land managers. However, the mean daily values are less accurate than $\mathrm{mm}$ (or even $\mathrm{m}^{3}$ if desired) since the exact duration of runoff is not known.

Table 3 summarizes the mean daily discharge results at strategic locations in the stream network. ID locations are shown in
Fig. 4 - most of the Cogolin fire was concentrated in a single catchment while the Vidauban fire stretched along several crests and touched a number of catchments. Pre-fire discharge values are the same in Tables 3a and 3b, respectively. Within-sensor post-fire discharge values are similar in Tables $3 \mathrm{a}$ and $3 \mathrm{~b}$, respectively, so runoff estimates are insensitive to index (dNBR or dNDVI) used. Differences in burned area described above have a negligible impact on runoff estimation. Between sensor differences show a pattern of slightly greater values for SPOT than Landsat: generally, post-fire discharge values are about $5 \%$ greater and ratio of post to pre-fire discharge values are about $5 \%$ greater.

The differences highlighted above remain reasonable in a context of fire impact estimation. Table $3 c$ shows the ratios of post-fire mean discharge values derived from different indices and sensors where values close to 1.00 indicate perfect agreement. Of the 32 ratios presented in Table $3 c$, only the SPOT dNDVI to Landsat dNDVI discharge value for Vidauban ID 1 is greater than $10 \%$ difference with a value of 1.13 . Although data were not available to validate runoff values, they are coherent for the different sensors and indices for both fires. Therefore, potential differences between estimated and real values would perhaps necessitate an adjustment in the runoff coefficients but would not put into question the modeling approach.

Post-fire discharge is greater than pre-fire values by a ratio of about 1.5-2 for Cogolin (Table 3a) and 2-2.5 for Vidauban (Table 3b). Relating these values to values found in the literature is difficult: Inbar et al. (1998) found little difference for low intensity storms while Cawson et al., 2013 found that runoff could be 100200 times greater on burned patches for large high intensity events. Folton et al. (2015) could not distinguish forest fire effects from drought effects in a burned catchment in SE France. As described above, fire-induced changes in discharge depend on local conditions and on both the absolute area (ha) and proportion of sub-catchment (ratio of burned surface to sub-catchment area) burned. A potential burn impact index could therefore be the product of burned area and proportion of sub-catchment burned (divided by 100 to scale it down). Unfortunately, this index cannot be calculated automatically and is not included in the POSTFIRE

Table 2

Runoff coefficients (RC) and infiltration values ( $\mathrm{mm}$ ) for land cover categories and pre/post-fire simulations. Rainfall is $60 \mathrm{~mm}$, and infiltration units are mm.

\begin{tabular}{|c|c|c|c|c|c|c|c|}
\hline Cover & Sparse & Shrubs & Forest & Vineyard & Grassland & Urban & Suburban \\
\hline $\mathbf{R C}$ & 0.6 & 0.2 & 0.1 & 0.5 & 0.3 & 0.8 & 0.6 \\
\hline Pre-fire Infiltration & 24 & 48 & 54 & 30 & 42 & 12 & 24 \\
\hline Post-fire Infiltration & 12 & 24 & 27 & 30 & 42 & 12 & 24 \\
\hline
\end{tabular}


Table 3a

Mean daily discharge $\left(\mathrm{m}^{3} \mathrm{~s}^{-1}\right)$ results for Landsat and SPOT sensors based on fire scars derived from dNBR and dNDVI classifications for the COGOLIN fire.

\begin{tabular}{|c|c|c|c|c|c|c|c|c|}
\hline \multirow[b]{2}{*}{ ID } & \multicolumn{4}{|c|}{ LANDSAT dNBR } & \multicolumn{4}{|c|}{ SPOT Dnbr } \\
\hline & Before & After & DIFF & Ratio & Before & After & DIFF & Ratio \\
\hline 1 & 3.5 & 7.2 & 3.7 & 2.06 & 3.6 & 7.7 & 4.1 & 2.14 \\
\hline 2 & 4.7 & 8.9 & 4.2 & 1.89 & 4.8 & 9.6 & 4.8 & 2.00 \\
\hline 3 & 2.5 & 3.5 & 1.0 & 1.40 & 2.4 & 3.5 & 1.1 & 1.46 \\
\hline \multirow[t]{2}{*}{4} & 8.6 & 13.8 & 5.2 & 1.60 & 8.7 & 14.7 & 5.9 & 1.68 \\
\hline & \multicolumn{4}{|c|}{ LANDSAT dNDVI } & \multicolumn{4}{|c|}{ SPOT dNDVI } \\
\hline ID & Before & After & DIFF & Ratio & Before & After & DIFF & Ratio \\
\hline 1 & 3.5 & 7.5 & 4.0 & 2.14 & 3.6 & 7.6 & 4.0 & 2.11 \\
\hline 2 & 4.7 & 9.2 & 4.5 & 1.96 & 4.8 & 9.6 & 4.8 & 2.00 \\
\hline 3 & 2.5 & 3.5 & 1.0 & 1.40 & 2.4 & 3.6 & 1.2 & 1.50 \\
\hline 4 & 8.6 & 14.1 & 5.5 & 1.64 & 8.7 & 14.7 & 6.0 & 1.69 \\
\hline
\end{tabular}

Table 3b

Mean daily discharge $\left(\mathrm{m}^{3} \mathrm{~s}^{-1}\right)$ results for Landsat and SPOT sensors based on fire scars derived from dNBR and dNDVI classifications for the VIDAUBAN fires.

\begin{tabular}{|c|c|c|c|c|c|c|c|c|}
\hline \multirow[b]{2}{*}{ ID } & \multicolumn{4}{|c|}{ LANDSAT dNBR } & \multicolumn{4}{|c|}{ SPOT dNBR } \\
\hline & Before & After & DIFF & Ratio & Before & After & DIFF & Ratio \\
\hline 1 & 4.5 & 10.8 & 6.3 & 2.40 & 4.3 & 11.7 & 7.4 & 2.72 \\
\hline 2 & 3.4 & 9.3 & 5.9 & 2.74 & 3.3 & 9.8 & 6.5 & 2.97 \\
\hline 3 & 2.1 & 4.9 & 2.8 & 2.33 & 1.9 & 5.0 & 3.0 & 2.58 \\
\hline \multirow[t]{2}{*}{4} & 7.6 & 12.1 & 4.5 & 1.59 & 7.5 & 12.5 & 5.0 & 1.67 \\
\hline & \multicolumn{4}{|c|}{ LANDSAT dNDVI } & \multicolumn{4}{|c|}{ SPOT dNDVI } \\
\hline ID & Before & After & DIFF & Ratio & Before & After & DIFF & Ratio \\
\hline 1 & 4.5 & 10.6 & 6.0 & 2.33 & 4.3 & 12.0 & 7.7 & 2.79 \\
\hline 2 & 3.4 & 9.1 & 5.7 & 2.68 & 3.3 & 9.9 & 6.6 & 3.00 \\
\hline 3 & 2.1 & 4.9 & 2.8 & 2.33 & 1.9 & 5.1 & 3.2 & 2.68 \\
\hline 4 & 7.6 & 11.9 & 4.3 & 1.57 & 7.5 & 12.9 & 5.4 & 1.72 \\
\hline
\end{tabular}

Table 3c

Post-fire discharge ratios between sensors and classification methods for the COGOLIN and VIDAUBAN fires (1.00 is perfect agreement).

\begin{tabular}{|c|c|c|c|c|c|c|c|c|}
\hline \multirow[b]{2}{*}{ ID } & \multicolumn{4}{|c|}{ COGOLIN } & \multicolumn{4}{|c|}{ VIDAUBAN } \\
\hline & $\begin{array}{l}\text { Land. } \\
\text { dNDVI/ } \\
\text { dNBR }\end{array}$ & $\begin{array}{l}\text { SPOT } \\
\text { dNDVI/ } \\
\text { dNBR }\end{array}$ & $\begin{array}{l}\text { SPOT } \\
\text { dNBR/ } \\
\text { Land. } \\
\text { dNBR }\end{array}$ & $\begin{array}{l}\text { SPOT } \\
\text { dNDVI/ } \\
\text { Land. } \\
\text { dNDVI }\end{array}$ & $\begin{array}{l}\text { Land. } \\
\text { dNDVI/ } \\
\text { dNBR }\end{array}$ & $\begin{array}{l}\text { SPOT } \\
\text { dNDVI/ } \\
\text { dNBR }\end{array}$ & $\begin{array}{l}\text { SPOT } \\
\text { dNBR/ } \\
\text { Land. } \\
\text { dNBR }\end{array}$ & $\begin{array}{l}\text { SPOT } \\
\text { dNDVI/ } \\
\text { Land. } \\
\text { dNDVI }\end{array}$ \\
\hline 1 & 1.04 & 0.99 & 1.07 & 1.01 & 0.98 & 1.03 & 1.08 & 1.13 \\
\hline 2 & 1.03 & 1.00 & 1.08 & 1.04 & 0.98 & 1.01 & 1.05 & 1.09 \\
\hline 3 & 1.00 & 1.03 & 1.00 & 1.03 & 1.00 & 1.02 & 1.02 & 1.04 \\
\hline 4 & 1.02 & 1.00 & 1.07 & 1.04 & 0.98 & 1.03 & 1.03 & 1.08 \\
\hline
\end{tabular}

model. It was derived manually for the dNDVI classifications and was correlated with both absolute increase in discharge $(r=0.76)$ and ratio increase $(r=0.78)$ when all 8 sub-catchments in Tables $3 \mathrm{a}$ and $3 \mathrm{~b}$ were included.

\section{Post-fire soil erosion}

Post-fire soil erosion depends on a wide range of factors: burn severity, burned area, soil texture and depth, slope, vegetation regrowth and rainfall characteristics (total and intensity) are frequently cited (Neary et al., 2011; Shakesby and Doerr, 2006;
Table 4

Sediment concentration $\left(\mathrm{T} \mathrm{m}^{-3}\right)$ values for soil erosion estimation. Among land covers, only vineyard is subject to erosion in the absence of fire.

\begin{tabular}{lllll}
\hline Slope range (\%) & Vineyard & Sparse & Shrubs & Forest \\
\hline $0 \leq 15$ & 0.002 & 0.001 & 0.005 & 0.004 \\
$15 \leq 30$ & 0.003 & 0.001 & 0.007 & 0.006 \\
$30 \leq 45$ & 0.006 & 0.001 & 0.009 & 0.008 \\
$\geq 45$ & 0.006 & 0.001 & 0.011 & 0.010 \\
\hline
\end{tabular}

Shakesby, 2011; Cawson et al., 2013). Unlike soil erosion in an agricultural context, post-fire erosion is usually active in only a narrow temporal window concentrated within the first winter after a fire, though studies have at times shown greater erosion rates in subsequent years due to rainfall characteristics (Prosser and Williams, 1998; Shakesby, 2011). Generally, most of the erosion occurs during one or a few major storms (Inbar et al., 1998; Cawson et al., 2013). It is therefore experimentally difficult to establish a soil erosion database that would enable multiple regressions to quantify erosion for a range of conditions, as has been done for agricultural erosion and the RUSLE model, for example. Fox et al. (2006) attributed indices to slope, texture, fire severity, and pre-fire vegetation to map erosion risk but this method cannot be used to estimate rates. The Erosion Risk Management Tool ERMiT - automatically estimates post-fire erosion at the slope scale in the US based on climate, soil texture, vegetation type, slope inclination and length, and burn severity (Robichaud et al., 2007; http://forest.moscowfsl.wsu.edu/cgi-bin/fswepp/ermit/er mit.pl).

The strategy adopted to map erosion in the POSTFIRE model uses a measure of soil erodibility and runoff volume. Each raster cell is attributed a sediment concentration $\left(\mathrm{T} \mathrm{m}^{-3}\right)$ that is reflective of soil erodibility depending on land cover and slope (Table 4), and this is multiplied by the $\mathrm{m}^{3}$ estimated in the runoff module to estimate sediment load $(\mathrm{T})$; this value is then converted to erosion rate ( $\mathrm{T} \mathrm{ha}^{-1}$ ) according to cell size. Soil texture is generally an important factor in determining soil erodibility and therefore sediment concentrations, but it was not used directly here. Texture data for 24 sediment samples taken from vineyards throughout the Giscle (Cogolin) catchment (unpublished data obtained from local wine-making cooperative) showed that soil texture varied little from one site to another, and values from cultivated foothills were similar to alluvial plain samples with high sand $(60-80 \%)$ and low clay contents (5-15\%). The geology and topography of the Vidauban site is similar to Cogolin but no texture data were available. Fox (2011) found coarser textures and shallower soils on $\mathrm{S}$-facing slopes than on $\mathrm{N}$-facing slopes in the Giscle (Cogolin) catchment. Soil texture and depth are partly accounted for indirectly through the vegetation classes since these are correlated with soil properties. Sparse vegetation is associated with very shallow stony soils with no or low fine sediment concentrations, and continuous forest is found on deeper finer-textured soils. Intermediate conditions - shrubs, tend to have shallower soils with more stone cover than for forest; sediment concentrations were attributed the highest values for shrubs because runoff would be expected to initiate more quickly, fine sediments were sufficiently abundant, and vegetation regrowth was slower than for forest. Fundamentally, data for texture were limited and there were no direct measurements linking texture to erosion. Similarly, slope length was not used to estimate sediment concentrations: it cannot be calculated automatically and it varies much less than in an agricultural setting where fields and roads act as boundaries, so it was considered less important than slope inclination. Sediment concentration values defined in Table 4 were inspired from a limited number of samples taken during a rainfall 
Table 5a

Soil erosion results for Cogolin fire.

\begin{tabular}{lrlrrll}
\hline Sensor & Index & $\begin{array}{l}\text { Mean } \\
\left(\mathbf{T ~ h a ~}^{-\mathbf{1}}\right)\end{array}$ & Area (ha) & Total (T) & $\begin{array}{l}\text { Std. Dev. } \\
\left(\mathbf{T ~ h a} \mathbf{~}^{-\mathbf{1}}\right)\end{array}$ & $\begin{array}{l}\text { Median } \\
\left(\mathbf{T ~ h a ~}^{-\mathbf{1}}\right)\end{array}$ \\
\hline Landsat & Vineyard & 0.56 & 521 & 294 & 0.19 & 0.59 \\
Landsat & dNBR & 2.12 & 2052 & 4351 & 1.14 & 2.44 \\
Landsat & dNDVI & 2.06 & 2179 & 4498 & 1.14 & 2.30 \\
SPOT & Vineyard & 0.62 & 516 & 319 & 0.21 & 0.61 \\
SPOT & dNBR & 2.23 & 2219 & 4956 & 1.11 & 2.52 \\
SPOT & dNDVI & 2.23 & 2242 & 4996 & 1.11 & 2.51 \\
\hline
\end{tabular}

Table 5b

Soil erosion results for Vidauban fires.

\begin{tabular}{lrlrrll}
\hline Sensor & Index & $\begin{array}{l}\text { Mean } \\
\left(\mathbf{T ~ h a}^{-\mathbf{1}}\right)\end{array}$ & Area (ha) & Total $\mathbf{( T )}$ & $\begin{array}{l}\text { Std. Dev. } \\
\left(\mathbf{T ~ h a}^{-\mathbf{1}}\right)\end{array}$ & $\begin{array}{l}\text { Median } \\
\left(\mathbf{T ~ h a ~}^{-\mathbf{1}}\right)\end{array}$ \\
\hline Landsat & Vineyard & 0.57 & 1113 & 636 & 0.20 & 0.59 \\
Landsat & dNBR & 2.47 & 10,999 & 27,200 & 0.81 & 2.52 \\
Landsat & dNDVI & 2.46 & 10,810 & 26,560 & 0.82 & 2.52 \\
SPOT & Vineyard & 0.57 & 1061 & 603 & 0.19 & 0.60 \\
SPOT & dNBR & 2.56 & 11,804 & 30,195 & 0.72 & 2.53 \\
SPOT & dNDVI & 2.56 & 12,454 & 31,920 & 0.72 & 2.53 \\
\hline
\end{tabular}

event shortly after the Cogolin fire, and these values can vary widely from one site to another according to local conditions (Cawson et al., 2013). Sediment concentrations are considered negligible for non-vineyard land covers and values in Table 4 correspond to burned surfaces for the land covers cited.

of the 8 soil erosion maps produced, only one for each fire is shown in Fig. 5a (Cogolin) and 5b (Vidauban) since the maps were nearly identical. Table 5 shows estimated erosion rates for vineyards and burned covers according to sensor, index, and burn scar. Mean and median post-fire erosion values tend to concentrate within about $2.0-2.5 \mathrm{~T} \mathrm{ha}^{-1}$. Although a direct comparison is difficult, these values are consistent with those cited by Fox (2011) for the Cogolin fire: erosion was estimated at $3.5 \mathrm{~T} \mathrm{ha}^{-1}$ based on sediments trapped in a sedimentation basin installed just after the fire, and this value included more rainfall events than were simulated here. Soil erosion rates and maps are coherent from one sensor and index to another, though erosion rates are greater for the SPOT images. This is due to greater runoff rates predicted in Module 2 (Tables 3a and $3 \mathrm{~b}$ ) and may also be influenced by slope distribution used to define sediment concentrations (Table 4) since calculated slopes are steeper for higher resolution DEMs (Yao et al.,
2010). Most of the within-fire scar between-index and betweensensor mean, median and total erosion rate ratios are close to 1.00 (Table 5c). The 1.20 value for the SPOT/Landsat dNDVI ratio (total erosion) for the Vidauban fire is greater than the others due to a combination of greater burned area classified and greater mean erosion rate. Total erosion (mean erosion * area) ratios tend to vary more than mean and median values since they combine differences in both burned area and erosion rate. For both fires, vineyard erosion rates are about $20-25 \%$ of post-fire values, but vineyards are eroded each and every year while post-fire erosion is limited in time.

\section{Discussion and model improvements}

Overall, the POSTFIRE model provides a coherent, locally adaptable, cost-effective framework for estimating potential impacts of a forest fire on runoff and erosion. Its simplicity makes it accessible to users with intermediate level GIS skills and some knowledge of hydrology and soil erosion. Burn scar area, runoff values, and erosion rates are all consistent when different sensors, indices, and fire scars are compared. Burn scar area estimation is similar to values reported by firefighters in the Prométhée data base and erosion rates are in the same range as field measured values (Fox, 2011).

The model's main weakness is its incapacity to simulate a storm hydrograph. Although the impacts of a fire on total runoff can be estimated, managers are generally more interested in peak discharge values, and the ratio of post-fire total runoff (or mean daily discharge) to pre-fire values may differ from the ratio of post-fire peak runoff to pre-fire peak.

In the long term, two significant improvements could potentially be brought to the model in addition to the storm hydrograph, though none of these are possible to include in a semi-automatic version today. The first is the calculation of the burn impact index where total sub-catchment area and proportion of sub-catchment area burned would be calculated automatically, as described above. This would show in a single map the sub-catchments most likely to be affected by the fire. The second is the development of an index of downslope vulnerability based on urban area in lowlands near the river channel. Changes in runoff have meaning most acutely in the light of urban and suburban flooding risk and semiautomatically combining post-fire increases in discharge with downstream vulnerability would provide the complete picture of post-fire runoff risk.
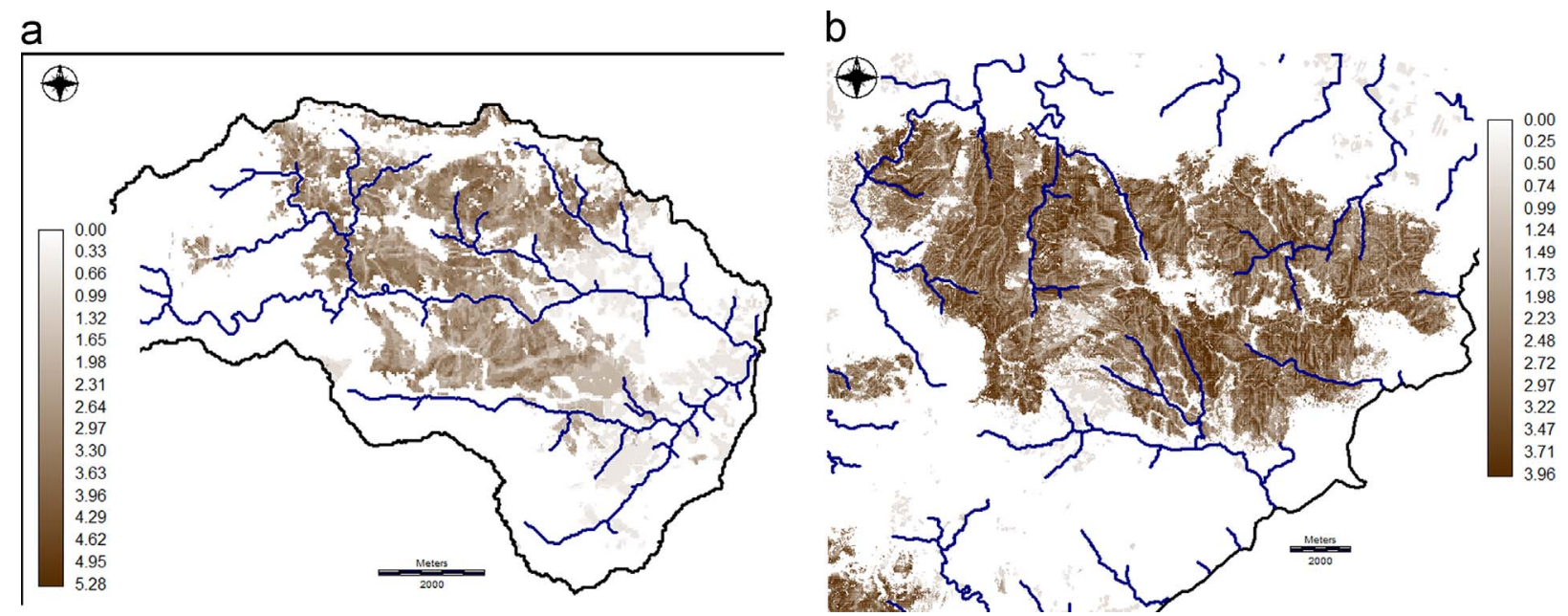

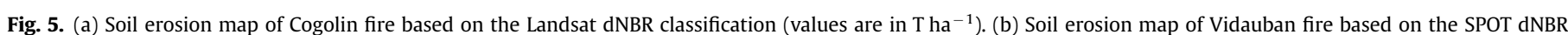
classification (values are in $\mathrm{T} \mathrm{ha}^{-1}$ ). 
Table 5c

Soil erosion between-index and between-sensor ratios for the COGOLIN and VIDAUBAN fires (1.00 is perfect agreement).

\begin{tabular}{|c|c|c|c|c|c|c|c|c|}
\hline \multirow[b]{2}{*}{ Erosion Variable } & \multicolumn{4}{|c|}{ COGOLIN } & \multicolumn{4}{|c|}{ VIDAUBAN } \\
\hline & $\begin{array}{r}\text { Land. dNDVI/ } \\
\text { dNBR }\end{array}$ & $\begin{array}{r}\text { SPOT dNDVI/ } \\
\text { dNBR }\end{array}$ & $\begin{array}{l}\text { SPOT dNBR/ } \\
\text { Land. dNBR }\end{array}$ & $\begin{array}{l}\text { SPOT dNDVI/Land. } \\
\text { dNDVI }\end{array}$ & $\begin{array}{r}\text { Land. dNDVI/ } \\
\text { dNBR }\end{array}$ & $\begin{array}{r}\text { SPOT dNDVI/ } \\
\text { dNBR }\end{array}$ & $\begin{array}{l}\text { SPOT dNBR/ } \\
\text { Land. dNBR }\end{array}$ & $\begin{array}{r}\text { SPOT dNDVI/Land. } \\
\text { dNDVI }\end{array}$ \\
\hline Mean & 0.97 & 1.00 & 1.05 & 1.08 & 1.00 & 1.00 & 1.04 & 1.04 \\
\hline Median & 0.94 & 1.00 & 1.03 & 1.09 & 1.00 & 1.00 & 1.00 & 1.00 \\
\hline Total & 1.03 & 1.01 & 1.14 & 1.11 & 1.01 & 1.06 & 1.11 & 1.20 \\
\hline
\end{tabular}

\section{Acknowledgments}

The authors are grateful for funding from the University of Nice - Sophia Antipolis's CSI Program.

\section{References}

Bassi S., Kettunen M., 2008. Forest fires: causes and contributing factors in Europe European Parliament, Policy Department, Economic and Scientific Policy. IP/A ENVI/ST/2007-15, PE 401.003.

Bastarrika, A., Chuvieco, E., Pilar Martín, M., 2011. Mapping burned areas from Landsat TM/ETM + data with a two-phase algorithm: balancing omission and commission errors. Remote Sens. Environ. 115, 1003-1012.

Cawson, J.G., Sheridan, G.J., Smith, H.G., Lane, P.N.J., 2013. Effects of fire severity and burn patchiness on hillslope-scale surface runoff, erosion and hydrologic connectivity in a prescribed burn. For. Ecol. Manag. 310, 219-233, DOI.org/10.1016/j. foreco.2013.08.016.

Chow, V.T., Maidment, D.R., Mays, L.W., 1988. Applied Hydrology, McGraw-Hill Series in Water Resources and Environmental Engineering. McGraw-Hill, USA.

Chuvieco, E., Martín, M.P. Palacios, A., 2002. Assessment of different spectral indices in the red-near-infrared spectral domain for burned land discriminations. Int. J. Remote Sens. 23, 5103-5110.

Chuvieco, E., Mouillot, F., Pereira, J.M.C., Oom, D., 2016. A new global burned area product for climate assessment of fire impacts. Glob. Ecol. Biogeogr., 1-11. http: //dx.doi.org/10.1111/geb.12440.

Cocke, A.E., Fulé, P.Z., Crouse, J.E., 2005. Comparison of burn severity assessments using Differenced Normalized Burn Ratio and ground data. Int. J. Wildland Fire 14, 189-198. http://dx.doi.org/10.1071/WF04010.

Doerr, S.H., Shakesby, R.A., Walsh, R.P.D., 2000. Soil water repellency: its causes, characteristics and hydro-geomorphological significance. Earth-Sci. Rev. 51, 33-65.

Eastman, R.J., 2016. IDRISI TerrSet Manual. Clark Labs, Clark University, Worcester, Massachussetts.

Folton, N., Andréassian, V., Duperray, R., 2015. Hydrological impact of forest-fire from paired-catchment and rainfall-runoff modelling perspectives. Hydrol. Sci. J. 60, 1213-1224. http://dx.doi.org/10.1080/02626667.2015.1035274.

Fox, D.M., 2011. Evaluation of the efficiency of some sediment trapping methods after a Mediterranean forest fire. J. Environ. Manag. 92, 258-265. http://dx.doi. org/10.1016/j.jenvman.2009.10.006.

Fox, D.M., Maselli, F., Carrega, P., 2008. Using SPOT images and field sampling for mapping burn severity and vegetation factors affecting post fire erosion risk. Catena 75, 326-335. http://dx.doi.org/10.1016/j.catena.2008.08.001.

Fox, D.M., Berolo, W., Carrega, P., Darboux, F., 2006. Mapping erosion risk and selecting sites for simple erosion control measures after a forest fire in Mediterranean France. Earth Surf. Process. Landf. 31 (5), 606-621. http://dx.doi.org/ $10.1002 /$ esp.1346.

Fox, D.M., Martin, N., Carrega, P., Andrieu, J., Adnès, C., Emsellem, K., Ganga, O., Moebius, F., Tortorollo, N., Fox, E.A., 2015. Increases in fire risk due to warme summer temperatures and wildland urban interface changes do not necessarily lead to more fires. Appl. Geogr. 56, 1-12, DOI.org/10.1016/j.apgeog.2014.10.001.

Goodwin, N.R., Collett, L.J., 2014. Development of an automated method for mapping fire history captured in Landsat TM and ETM + time series across Queensland, Australia. Remote Sens. Environ. 148, 206-221, DOI.org/10.1016/j. rse.2014.03.021.

Inbar, M., Tamir, M., Wittenberg, L., 1998. Runoff and erosion processes after a forest fire in Mount Carmel, a Mediterranean area. Geomorphology 24, 17-33.

JRC Technical Report, 2013. Forest fires in Europe, Middle East and North Africa. Joint report of JRC and Directorate-General Environment. Eur. Comm.

Key, C.H., Benson, N.C., 2006. Landscape assessment: ground measure of severity, the composite burn index, and remote sensing of severity, the Normalized Burn Ratio. In: Lutes, D.C., Kean, R.E., Caratti, J.F., Key, C.H., Benson, N.C., Sutherland, S., Gangi, L.J. (Eds.), FIREMON: Fire Effects Monitoring and Inventory System. USDA Forest Service Gen. Tech. Rep. RMRS-GTR-164-CD: LA1-51.

Lavabre, J., Martin, C., 1997. Impact d'un incendie de forêt sur l'hydrologie et l' érosion hydrique d'un petit bassin versant méditerranéan. Human Impact on Erosion and Sedimentation (Proceedings of Rabat Symposium S6, April 1997): IAHS Publication, no. 245, pp. 39-47.

Lentile, L.B., Holden, Z.A., Smith, A.M.S., Falkowski, M.J., Hudak, A.T., Morgan, P., Lewis, S.A., Gessler, P.E., Benson, N.C., 2006. Remote sensing techniques to assess active fire characteristics and post-fire effects. Int. J. Wildland Fire 15, 319-345. http://dx.doi.org/10.1071/WF05097.

Maselli, F., Conese, C., Rodolfi, A., Bottai, L., 1996. Characterization of forest recovery after fires in Mediterranean area by means of multitemporal Landsat TM scenes. In: Parlow, E. (Ed.), Progress in Environmental Remote Sensing and Applications. A.A. Balkema, Rotterdam, pp. 73-76.

Miller M.E., Billmire M., Elliot W.J., Endsley K.A., Robichaud P.R., 2015. Rapid response tools and datasets for post-fire modelling: linking earth obsevations and process-based hydrological models to support post-fire remediation. The International Archives of the Photogrammetry, Remote Sensing and Spatial Information Sciences, Volume XL-7/W3, 2015 36th International Symposium on Remote Sensing of Environment, 11-15 May 2015, Berlin, Germany. Doi:10.5194/isprsarchives-XL-7-W3-469-2015.

Moody, J.A., Martin, R.G., 2015. Measurements of the initiation of post-wildfire runoff during rainstorms using in situ overland flow detectors. Earth Surf. Process. Landf. . http://dx.doi.org/10.1002/esp.3704

Moody, J.A., Shakesby, R.A., Robichaud, P.R., Cannon, S.H., Martin, D.A., 2013. Current issues related to post-wildfire runoff and erosion processes. Earth Sci. Rev. 122, 10-37. http://dx.doi.org/10.1016/j.earscirev.2013.03.004.

Moriondo, M., Good, P., Durao, R., Bindi, M., Giannakopoulos, C., Corte-Real, J., 2006. Potential impact of climate change on fire risk in the Mediterranean area. Clim. Res. 31, 85-95.

Neary D.G., Koestner K.A., Youberg A., Koestner P.E., 2011. Rill and gully formation following the (2010) Schultz fire. Paper presented at the 24th Annual Symposium of the Arizona Hydrological Society; Watersheds near and far: response to changes in climate and landscape; September 18-20, (2010); Flagstaff, AZ. 6 p.

Prosser, I.P., Williams, L., 1998. The e€ect of wild ${ }^{\mathbb{R}}$ re on runo€ and erosion in native Eucalyptus forest. Hydrol. Process. 12, 251-265.

Robichaud, P.R., Hungerford, R.D., 2000. Water repellency by laboratory burning of four northern Rocky Mountain forest soils. J. Hydrol. 231-232, 207-219.

Robichaud P.R., Elliot W.J., Pierson F.B., Hall D.E., Moffet C.A., Ashmun L.E., 2007. Erosion Risk Management Tool (ERMiT) User Manual (version 2006.01.18). USDA Forest Service, General Technical Report RMRS-GTR-188.

Rogan, J., Yool, S.R., 2001. Mapping fire-induced vegetation depletion in the Peloncillo Mountains, Arizona and New Mexico. Int. J. Remote Sens. 22, 3101-3121.

Shakesby, R.A., 2011. Post-wildfire soil erosion in the Mediterranean: Review and future research directions. Earth-Sci. Rev. 105, 71-100. http://dx.doi.org/ 10.1016/j.earscirev.2011.01.001.

Shakesby, R.A., Doerr, S.H., 2006. Wildfire as a hydrological and geomorphological agent. Earth Sci. Rev. 74, 269-307.

Sunderman, S.O., Weisberg, P.J., 2011. Remote sensing approaches for reconstructing fire perimeters and burn severity mosaics in desert spring ecosystems. Remote Sens. Environ. 115, 2384-2389. http://dx.doi.org/10.1016/j. rse.2011.05.001.

Vieira, D.C.S., Fernández, C., Vega, J.A., Keizer, J.J., 2015. Does soil burn severity affect the post-fire runoff and interrill erosion response? A review based on metaanalysis of field rainfall simulation data. J. Hydrol. 523, 452-464. http://dx.doi. org/10.1016/j.jhydrol.2015.01.071.

Yao, C. McCool, D.K., Elliot, W.J., 2010. DEM resolution effects on hillslope length and steepness estimates for erosion modelling. ASABE Annual International Meeting, (June) 20-23, 2010, Pittsburgh, Pennsylvania. 